\title{
Psychometric properties of a Food Buying Styles Scale (EEC-ALI) in University Students
}

\author{
Marianela Denegri a ${ }^{2} \oplus$, Constanza García ${ }^{a}{ }^{\oplus}$, Nicolle González ${ }^{a}{ }^{\circledR}$, \\ Herman Elgueta $^{\mathrm{b}}{ }^{(0)}$, Clementina Hueche ${ }^{\mathrm{a}}{ }^{\circ}$, \& Berta Schnettler $^{\mathrm{a}}{ }^{3}{ }^{3}$
}

Universidad de la Frontera, Temuco, Chile ${ }^{\mathrm{a}}$, Universidad de Magallanes,
Punta Arenas, Chile ${ }^{\mathrm{b}}$.

ABSTRaCT

The object of the present reserach was to assess the psychometric properties of the Food Buying Styles Scale (Escala de Estilos de Compra de Alimentos - EEC-ALI) based on the Buying Styles Scale adapted by Denegri, Peñaloza, Elgueta and Sepúlveda (unpublished manuscript). This scale assesses planning, impulsiveness and compulsiveness with regards to food buying behavior. The sample consisted of 369 university students, male and female, from northern, central and southern Chile. We examined reliability and validity indicators. The analyses showed adequate reliability parameters for its three dimensions.Regarding its internal structure, when subjected to CFA with 18 items, the results were not satisfactory, indicating adjustment difficulties. Therefore, a new analysis was carried out with a simplified version of the instrument, eliminating some items and in order to have the optimal number of 4 items per latent variable (Kline, 2011). In the second stage, the CFA maintained the three-factor model, excluding 6 items that showed the lowest factor loadings in the previous analysis, and were the least theoretically sound. The new analysis produced more adequate levels of goodness of fit, concluding that the three-factor model with a total of 12 items can be considered adequate for its use in the analysis of food buying styles in young people and specifically university students.

\section{Keywords}

buying styles; planning; impulsiveness; compulsiveness; psychometric properties

\section{RESUMEN}

El objetivo de la presente investigación fue evaluar las propiedades psicométricas de la Escala de Estilos de Compra de Alimentos (EEC-ALI) basada en la Escala de Estilos de Compra adaptada por Denegri, Peñaloza, Elgueta y Sepúlveda (manuscrito inédito) . Esta escala evalúa la planificación, la impulsividad y la compulsión con respecto al comportamiento de compra de alimentos. La muestra consistió en 369 estudiantes universitarios, hombres y mujeres, del norte, centro y sur de Chile. Examinamos los indicadores de confiabilidad y validez. La escala mostro parametros de confiabilidad adecuados para sus tres dimensiones. En cuanto a su estructura interna, al someterla a AFC con 18 items, los resultados no fueron satisfactorios indicando dificultades de ajuste. Por tanto, se realizó un nuevo análisis con una versión simplificada del instrumento, eliminando algunos ítems para tener el número óptimo de 4 ítems por variable latente (Kline, 2011). En la segunda etapa, el AFC mantuvo el modelo de tres factores, excluyendo 6 ítems que mostraban las cargas factoriales más bajas en el análisis anterior, y eran los menos sólidos teóricamente. El nuevo análisis produjo niveles más adecuados de bondad de ajuste, concluyendo que el modelo de tres factores con un total de 12 ítems puede considerarse adecuado para su uso en el análisis de estilos de compra de alimentos en jóvenes y específicamente en estudiantes universitarios.

\section{Palabras Claves}

estilos de compra; planificación; impulsividad; compulsividad; propiedades psicométricas.

\footnotetext{
1 This research was sponsored by FONDECYT projects No. 1130165

2 Correspondence about this article should be addressed Marianela Denegri: marianela.denegri@ ufrontera.cl

3 Conflicts of Interest: The authors declare that the research was conducted in the absence of any commercial or financial relationships that could be construed as a potential conflict of interest.
} 


\section{Denegri, García, González, Elgueta , Hueche, \& Schnettler}

Propiedades psicométricas de una escala de estilos de compra de alimentos (EEC-ALI) en estudiantes universitarios

The world economic scenario has changed drastically in recent decades. Every day, people have to carry out a large number of commercial transactions which necessarily imply choosing between the many varieties of products available in the market.

These changes have resulted in new configurations of consumer segments and their needs and expectations, with a marked effect on how people relate to buying and consumption (Denegri et al., 2012; Denegri \& Martínez, 2004). We live in a "consumer society", in which consumption has become established as a natural need (Campbell, 2004), occupying an increasingly important space in both private life and social interaction (Denegri \& Martínez, 2004; Martínez, 2007; Moulian, 1997).

Van Raaij (1993) states that one of the most important effects of the modification of market structure and functioning caused by globalisation has been a marked tendency towards individualisation. As a result subjects select products through which they express their individuality, meaning that products are not consumed solely for their functional properties, but also for the psychological and social benefits and characteristics attributed to them by users.

This has led to the concept of symbolic buying (Luna-Arocas, 1995; Schnettler et al., 2010) in which products transcend their physical dimension to become impregnated with cultural and social significations, allowing people to express and communicate both real aspects of their identities and those linked to the ideal Ego through the choice and use of products. This aspect would be present in all buying and consumption decisions, regardless of the nature of the product, and would therefore also be applicable to buying decisions regarding products of prime necessity.

From this angle the consumer's conduct is closely related to many variables, such as perceptions, learning, convictions, beliefs, motivations and personality styles (Schiffman \& Lazar, 2005) which play a part in final consumption decisions (Denegri, 2010; Denegri, García, González, \& Sepúlveda, 2014). Thus buying behaviour will not be unitary, nor will it always present the same characteristics: different consumers will make their consumption decisions in different ways (Coward \& Goldsmith, 2007; Lysonski, Durvasula, \& Zotos, 1996; Siu et al., 2001;). Studies indicate essentially that consumers are influenced by both personal and non-personal factors in expressing their 
consumption preferences, and that these factors vary between different segments and markets (Kongsompong, 2006; McDonald, 1994).

Sproles and Kendall (1986) identify three focuses for understanding consumers' decision-making in buying or consumption: the psychographical focus, the consumer type, and the consumer's characteristics. The latter is the focus of the consumer's mental orientation in decision-making and therefore the most powerful for consumption studies (Tanksale, Neelam, \& Venkatachalam, 2014).

Thus the different variables which affect consumer behaviour acquire particular configurations which form buying styles, defined as the set of basic attitudes underlying daily buying decisions for various kinds of goods and services (Luna-Arocas, 1998; Walsh, Mitchell, \& Hennig-Thurau, 2001). They are also understood as consumers' particular forms of acting, strongly related to their everyday consumption acts and processes, for example where a service or idea is bought or consumed (Luna-Arocas, 1998). They underline the cognitive and affective dimensions found at the base of processes, providing wide-ranging explanatory constructions for measuring the characteristics of consumption decisions (Tarnanidis, Owusu-Frimpong, Nwankwo, \& Omar, 2015). The specific variables considered here are planning, impulsiveness and compulsiveness (Denegri, Fernández, Iturra, Palavecinos, \& Ripoll, 1999): planning refers to a buying style focused on the organisation and hierarchisation of needs, including operational elements related with the characteristics of the product, the possibility of changing it and the relation with the vendor (Denegri et al., 1999; Luna-Arocas \& Fierres, 1998;) the impulsive buying style implies the absence or minimal presence of planning, little cognitive appreciation of the consequences of the purchase, and guidance by the emotions and the symbolic significance of the product (Rodríguez, Otero-López, \& Rodríguez, 2001); and finally the compulsive buying style is related with an obsessive desire to buy an object as a form of compensation for anxiety - an irresistible desire constituting addictive behaviour (Black, 2007; Kukar-Kinney, Ridway, \& Monroe, 2009; Flight, Roundtree, \& Beatty, 2012).

Although the majority of studies for determining buying styles have used the Consumer Styles Inventory (CSI) designed by Sproles and Kendall (1986), in the present work we used the "Ir de compras" ("going shopping") instrument developed by LunaArocas and Fierres (1998) in the University of Valencia (Spain). This instrument originally included nine different scales: rationality in buying, impulsiveness in buying, compulsiveness in buying, social consumption, attitude to debt, materialism, attitude to 
clothes, attitude to advertsing, and concern for corporal image. The scale has been translated into different languages and used in many countries, e.g. Italy, Slovenia, Spain, Portugal, England and the United States (Kranjecec \& Polic, 2003; Luna-Arocas, 1999; Luna-Arocas, Gallucio, Costa, \& Miranda, 2001; Pereira, Antunes, \& Nobre, 2011; Tang, Luna-Arocas, \& Quintanilla, 2001). In Latin America it has been adapted and used in countries like Argentina (Ferrari \& Luna-Arocas, 2000), Chile (Gebaüer, Schäfer, \& Soto, 2003) and Colombia (Luna-Arocas, Puello, \& Botero, 2004). From the first, in the various research works carried out to assess its psychometric properties in the target population, it has demonstrated its constant reliability (as shown in Table 1) and its internal validity. Table 1

Reliability assessment of the original version of the scale.

\section{Alpha Coefficient}

\begin{tabular}{lccc}
\hline \multicolumn{1}{c}{ Scales } & $\begin{array}{c}\text { Spain } \\
\text { (Luna-Arocas } \\
\text { and Fierres } \\
\text { 1998; Luna- } \\
\text { Arocas 2001). }\end{array}$ & $\begin{array}{c}\text { Argentina } \\
\text { (Ferrari and } \\
\text { Luna-Arocas } \\
\text { 2000) }\end{array}$ & $\begin{array}{c}\text { Colombia } \\
\text { (Luna-Arocas et al. } \\
\text { 2004) }\end{array}$ \\
\hline Attitude towards debt & .62 & Low value & Low value \\
\hline Rationality in buying & .74 & .85 & .80 \\
\hline Impulsiveness in buying & .82 & .81 & .81 \\
\hline Compulsiveness in buying & .83 & .82 & .84 \\
\hline Social consumption & .84 & .83 & .87 \\
\hline Materialism scale & .80 & .81 & .76 \\
\hline Attitude towards clothes & .76 & .83 & .85 \\
\hline Attitude towards advertising & .74 & .82 & .80 \\
\hline Concern for corporal image & .65 & .93 & .89 \\
\hline
\end{tabular}

In Chile particularly, this instrument has been applied in many samples and different adaptations (Denegri et al., 2010; Denegri et al., 2012; Denegri et al., 2014; Denegri, Sepúlveda, \& Godoy, 2011; Gebauer, Schäfer, \& Soto, 2003). In general only three of the nine scales included in the original instrument created by Luna-Arocas and Fierres (1998) have been used. They have been grouped into a new questionnaire called the Scale of Attitudes Towards Buying (Escala de Actitudes Hacia la Compra) which was validated by Gebauer, Schäfer and Soto (2003). It consisted of 18 items included in the dimensions of rationality, impulsiveness and compulsiveness. Previous research carried out with this adapted scale in a university population showed that it has appropriate psychometric properties both for the reliability (see Table 2) and internal validity indices, for each of the dimensions of the scale and for the instrument as a whole 
Table 2.

Reliability assessment of the version of the scale adapted for Chile.

\begin{tabular}{lccc}
\hline \multicolumn{1}{c}{$\begin{array}{c}\text { Scale of Attitudes } \\
\text { towards Buying }\end{array}$} & \multicolumn{3}{c}{ Alpha Coefficient } \\
\cline { 2 - 4 } & \multicolumn{3}{c}{ Chile } \\
\cline { 2 - 4 } & (Denegri et al. & (Denegri et al. & (Denegri et al. \\
Rationality in buying & 2010) & .78 & .79 \\
\cline { 2 - 4 } Impulsiveness in buying & .85 & .83 & .80 \\
Compulsiveness in buying & .86 & .90 & .86 \\
\hline
\end{tabular}

Based on a review of the state of the art and the precedents derived from the theoretical framework which support the creation of the Scale, and to ensure greater congruence in the construct to be measured - since we are not only talking of attitudes but also including elements of buying decisions - in the latest review of the scale, which included confirmatory analysis, it was decided to change the name to Buying Styles Scale (Escala de Estilos de Compra - EEC) (Denegri, Peñaloza, Elgueta, \& Sepúlveda, unpublished).

Dittmar (2005) establishes that psychologically motivated buying appears to be a growing phenomenon in current buying behaviour, and is closely linked to people's need to improve their self-concept, their personal image, their self-esteem or their relations with others. In the particular case of young people, and considering the stage they have reached in consolidation of their identity, access to consumption comes to represent access to symbols and signs which favour self-realisation and serve their incorporation into a community of equals (UNDP/World Youth Report 2003). Within the scenario of buying decisions facing young people, we identified those applicable to products of prime necessity, such as food consumption. As with the choice of other products, buying of these products is governed by psychological, social, cultural, economic and biological forces, in addition to strictly nutritional factors and those concerning the utilitarian function for the body (Schnettler et al., 2012). Food acts as a product of hedonism and social construction, influencing personal and social self-definition and providing a centre for experiences of social enjoyment, mainly enjoyed day by day in the company of family and friends (Schnettler, Miranda, Sepúlveda, \& Denegri, 2011).

Research linked to food buying carried out in university students indicates that factors like studies, the family, friends and the university environment condition food attitudes and behaviour (Espinoza, Rodríguez, Gálvez, \& McMillan, 2011; Schnettler et al., 2011; Troncoso \& Amaya, 2009) furthermore, it is recognised that the lifestyle of 


\section{Denegri, García, González, Elgueta , Hueche, \& Schnettler}

young people is expressed in a set of behaviours towards certain products, which may sometimes be healthy and sometimes damaging to the health (Díaz, Carús, Macossay, \& Barbosa, 2010).

Food is a consumer product charged with social and symbolic significates which have close links with the individual's emotions (Luna-Arocas \& Bech-Larsen, 2004). Macias, Gordillo and Camacho (2012) stress that food choice styles are modified progressively by different factors which alter social and/or family dynamics and interactions, and this is particularly important in the stage reached by young university students, a high percentage of whom leave home to study and assume the responsibility for their food and for when, how and what they eat. This has a direct impact on the development of healthier eating habits. The importance of knowing the food buying styles of university students is recognised because of their impact on the students' present and future health and quality of life.

Specific instruments are therefore necessary to enable food buying styles to be characterised. The present study is based on the Buying Styles Scale of Denegri, Sepúlveda, Peñaloza and Elgueta (unpublished) and is designed to measure the predominant Food Buying Styles of university students. For the specific purposes of this study it is called the Food Buying Styles Scale (Escala de Estilos de Compra de Alimentos - EEC-ALI), and its psychometric properties will be proved in the study.

Empirical proof of the psychometric guarantees of tests as measurement instruments is based on practical proof of the authenticity (validity) and accuracy (reliability) of the content assessed. Goodness of fit in these psychometric properties of tests provides scientific backing for psychologically-based measurements (Rodríguez \& Molerio, 2012). In this specific case, in order to select one of the many types of validity proposed, we selected the source of validity described by Abad, Olea, Ponsoda and García (2011), evidence based on internal structure, which is based theoretically on examination of the relations between the test items, and which proves whether all the data fit a concrete factorial solution in the case of a confirmatory analysis.

Based on the above, the following research question was adopted: Is the Food Buying Styles Scale (EEC-ALI) reliable and valid for application in Chilean university students? In order to answer this question, we proposed to assess the psychometric properties of the Food Buying Scale (EEC-ALI) in a sample of university students from northern, central and southern Chile. Specifically, we sought to: a) examine the reliability 
of the scale and its dimensions by assessing its internal consistency; b) examine validity indicators of the scale and its dimensions assessing its factorial structure

\section{Method}

\section{Participants}

The population consisted of students in some of the 25 universities of the Consejo de Rectores de Chile (CRUCH) located in northern, central and southern Chile. The sample was determined by convenience sampling, and consisted of 369 unpaid university student volunteers of both sexes, in the first and third years of their undergraduate degree courses. $46 \%$ of the participants were men and $54 \%$ were women; the average age of the sample was 21 years $(S D=2.27) ; 8 \%$ of the students were in northern Chile, $53 \%$ in the central zone of the country and $39 \%$ in the south.

The sample size was considered adequate for the analysis considering that more than 5 participants per item tested were ensured, as recommended by Nunnally (1967) and Martínez-Arias (1995).

\section{Design}

This research is an instrumental study, since according to research methodologies in Psychology all studies aimed at developing tests and apparatus are considered to fall into that category. This includes the design and adaptation of tests and study of their psychometric properties (León \& Montero, 2002; Montero \& León, 2002; Montero \& León, 2005).

\section{Instrument}

For the purposes of this work, we used the Food Buying Styles Scale (EEC-ALI), based on the Buying Styles Scale (EEC) of Denegri, Peñaloza, Elgueta and Sepúlveda (unpublished), adapted for food buying by the research team. The instrument is selfadministered and is designed for collective application. It consists of 18 items in a 6-Point Likert format, going from "disagree completely" (1 point) to "agree completely" (6 points), to measure food product buying styles in three dimensions: planning (4 items), and impulsiveness and compulsiveness ( 7 items each). All three dimensions are measured directly, and their values are calculated from the mean partial score for each item.See Table 3 for more details about the items. 


\section{Denegri, García, González, Elgueta , Hueche , \& SchnetTler}

\section{Procedure}

The research was part of the Fondecyt 1190017 and 1130165 projects, which were approved by the Scientific Ethics Committee of the University of La Frontera.. University authorities were contacted formally to invite them to participate in the research. Once contact had been made and the approval of the authorities obtained, students were invited to volunteer to take part in the study, explaining the objects and guaranteeing anonymity and confidentiality. Those who agreed to participate voluntarily and with no reward were asked to sign a digital informed consent. The questionnaires were then applied personally using an electronic response recording method (Question Pro), supervised by the research team.

\section{Data analysis}

To achieve the first objective, of obtaining evidence of reliability, internal consistency was analysed through the estimation of the $\alpha$-ordinal indicator as recommended by Zumbo, Gaderman and Zeisser (2007) for ordinal items.

To determine the source of validity mentioned in evidence based on internal structure, the second object, a confirmatory factorial analysis (CFA) was done of the structure of the dimensions in order to discover the common variance which originates the factors of a given construct, i.e. a multivariant statistical technique used for studying the dimensions or factors which underlie the relations between the variables (Abad, Garrido, Olea, \& Ponsoda, 2006). This procedure was carried out in two stages: one to assess the internal structure according to the original three-factor scale with the corresponding items adapted for food buying, and a second to analyse the proposed changes to the scale, assessed from the results of the first. For these procedures, three aspects were considered important according to Abad et al. (2011). First the parameter to be used was estimated, giving the measurements which would minimise the discrepancies between the variances and the covariance reproduced by the model, and those observed in the sample. The method selected was Weighted Least Squares Mean and Variance Adjusted (WLSMV), a robust estimator suitable for categoric data (Brown, 2006; Muthén \& Muthén, 2007; Muthén \& Muthén, 2010). To assess the model we used as indicators of of fitthe Chi squared index $\left(\chi^{2}\right)$, the root mean square error of approximation (RMSEA)and the Comparative Fit Index (CFI). Considering that the parameters for the fit indices always have a certain degree of arbitrariness (Lance, Butts, \& Michels, 2006; Marsh, Hau, \& Wen, 2004), the "local" poor fits of the model must always be studied 
with care. The following cut-off points were considered for this study: $\chi^{2}$ with a $p<0.05$ (Abad et al. 2011), RMSEA below 0.1 (Browne \& Cudeck, 1993), and CFI > 0.95 (Hu $\&$ Bentler, 1999). The last aspect to complete the CFA was a visual representation of the model, since this facilitates a quick, effective comprehension of it.

In both stages of the analysis we used the MPLUS statistics programme, Version 7 (Muthén \& Muthén, 2015) which is suitable for procedures based on structural equation models.

\section{Results}

Regarding the reliability of the domains of the scale, the following $\alpha$-ordinal values were found for: Planning .867, Impulsiveness .826 and Compulsiveness .897, showing appropriate reliability parameters.

With regards to the validity of the scale and its domains according to evidence based on internal structure, the CFA of the measurment model revealed inadecuate goodness of fit in the first instance, with the following results: $\chi^{2}(132)=706.730, p<$ $0.001, \mathrm{RMSEA}=0.158, \mathrm{CFI}=0.882$. With the cut-off points outlined above, none of the indicators would fall into the acceptable ranges indicating a good fit. Based on the information obtained from this analysis we concluded that the model with three correlated factors and a total of 18 items is not acceptable. We therefore decided to perform a new analysis with a simplified version of the instrument, by removing some items to have an optimal number of 4 items per latent variable, as has been suggested by some experts (Kline, 2011).

In this second stage the CFA of the three-factor model was done after exclusion of 6 items that showed the lowest factor loadings in the previous analysis, and which were also the least theoretically sound with regards to the measured domains (the items 7,10 , $11,15,17$ and 18 were removed from the scale). The new analysis produced more adequate levels of goodness of fit, with results as follows: $\chi^{2}(930)=2204.779, p<0.001$, $\mathrm{RMSEA}=0.095, \mathrm{CFI}=0.966$. Although $\chi^{2}$ falls outside the expected range, this indicator has been proven problematic as it is susceptible to inflation due to sample size, (Abad et al., 2011). Thus we concluded that that the three-factor model (see Figure 1) with a total of 12 items (see Table 3) can be considered acceptable. It is worth noting that the values for the $\alpha$-ordinal indicators remain virtually unchanged for the scale with 12 items. 


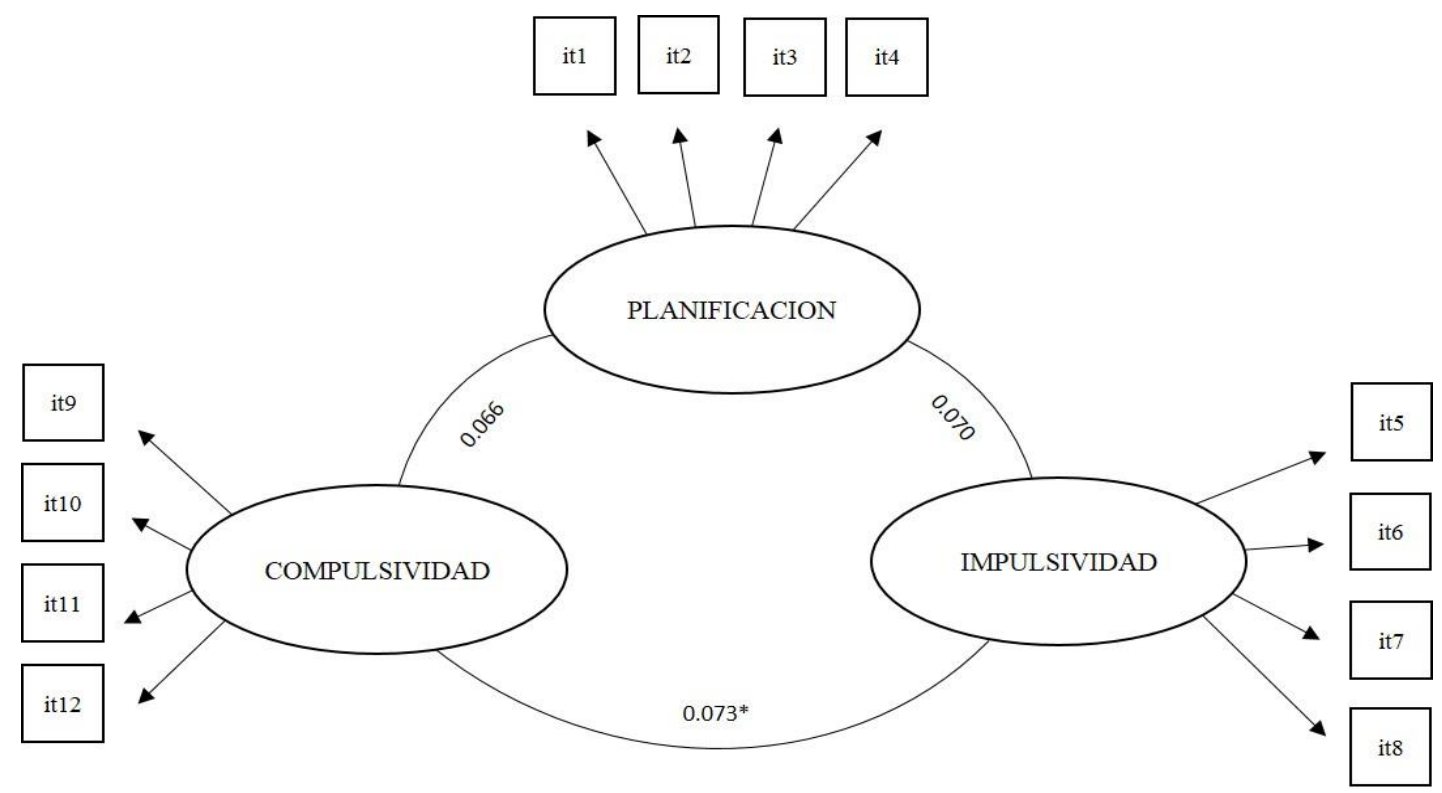

Figure 1. Model obtained for the CFA and standardised correlations between factors. Note. *p $<.001$. Glorsario. Planificación - planning. Impulsividad - impulsiveness. Compulsividad compulsiveness

Table 3.

Non-standardised factorial charges of items per factor.

\section{Factors}

\begin{tabular}{|c|c|c|c|c|}
\hline & Items & Planning & Impulsiveness & Compulsiveness \\
\hline 1 & $\begin{array}{l}\text { Before I buy food I make a list of what I } \\
\text { need }\end{array}$ & $1.000^{*}$ & & \\
\hline 2 & I keep a record of what I spend on food & $1.408 *$ & & \\
\hline 3 & I check the receipts of my food purchases & $1.128^{*}$ & & \\
\hline 4 & $\begin{array}{l}\text { I habitually note my current and extra } \\
\text { food costs }\end{array}$ & $1.312^{*}$ & & \\
\hline 5 & $\begin{array}{l}\text { When I see some kinds of food I } \\
\text { immediately feel an urge to buy them }\end{array}$ & & $1.000 *$ & \\
\hline 6 & $\begin{array}{l}\text { Sometimes I have been so fascinated by a } \\
\text { kind of food that I just have to buy it }\end{array}$ & & $0.926 *$ & \\
\hline 7 & $\begin{array}{l}\text { I love buying food which I had not } \\
\text { thought of buying }\end{array}$ & & $1.016^{*}$ & \\
\hline 8 & $\begin{array}{l}\text { I have taken the opportunity to buy a kind } \\
\text { of food which I knew I would miss if I did } \\
\text { not buy it immediately }\end{array}$ & & $1.011^{*}$ & \\
\hline 9 & $\begin{array}{l}\text { I cannot control myself when I am buying } \\
\text { food }\end{array}$ & & & $1.000 *$ \\
\hline 10 & $\begin{array}{l}\text { I sometimes need to buy food just for the } \\
\text { sake of buying something }\end{array}$ & & & $1.135^{*}$ \\
\hline 11 & $\begin{array}{l}\text { I know I buy too much food but I cannot } \\
\text { help it }\end{array}$ & & & $1.158 *$ \\
\hline 12 & $\begin{array}{l}\text { If I do not buy food one day I feel an } \\
\text { urgent need to try to buy something }\end{array}$ & & & $1.043^{*}$ \\
\hline
\end{tabular}

Note: ${ }^{*} p<.001$ 


\section{Discussion}

Current consumption presents a marked segmentation of the market, with large marketing companies conscious of the factors which may influence consumers' buying decisions, as well as their attitude and buying behaviour when purchasing a product, good or service (Tanksale, Neelam, \& Venkatachalam, 2014). It is therefore essential to have information on the buying behaviour of consumers in various ambits of consumption, in order to implement effective strategies oriented towards determining consumers' most common buying habits, understanding their decision-making styles and awareness of these practices (Tanksale et al., 2014).

EEC (Denegri, Sepúlveda, Peñaloza, \& Elgueta, unpublished) is a scale for measuring buying styles with a broad theoretical base and good performance over years of use, making it very useful in this context. However its degree of sensitivity to the different cultural orientations which coexist between societies that use scales to measure consumer behaviour is under discussion (Tarnanidis et al., 2015).

In this new orientation towards food consumption, considering the importance of this basic need and its social and symbolic significates as well as its impact on health, assessment of the Food Buying Styles Scale (EEC-ALI) is indispensable. To do this we applied two procedures in this study designed to obtain evidence on its psychometric performance in university students.

Analysis of the reliability of the scale with this sample presents a high correlation between items, producing an index which allows us to state that it is a reliable test.

The data collected were also used to contrast the three-factor model proposed in the original version, using weighted least squares mean and variance adjusted (WLSMV), a robust estimator suitable for categoric data. It was found that, after the elimination of certain items, an appropriate fit was obtained between the data and the model, from which it may be concluded that the three-dimension structure can be used.

The evidence therefore suggests that EEC-ALI is suitable for use in assessment and research in this population, as a reliable, valid measurement for studying the construct.

This conclusion gives rise to reflections linked to the promotion of responsible food buying behaviour in the university environment. It is important that this should include the various spaces in which students' lives are played out, starting from the basis that buying styles are constructed and expressed by people in their everyday environment. 
As part of current concepts of higher education, universities' perspectives of their role have changed. The principal object and meaning of the universities' action is now the student, seen as a holistic being with a range of needs and social roles which he or she must comply with as part of his/her social responsibility (Barraza \& Ortíz, 2012). However to do this the student must be aware of what mechanism he/she is using to select and buy a food product. This will promote greater responsibility among students for their own health.

From the findings collected in the statistical analyses and discussion of the results, we may conclude that this study is projected as a contribution to psychological research in Chile, providing an in-depth methodological analysis of an instrument which assesses food buying styles among university students.

The adaptation of the instrument and its validation in a Chilean sample opens the way to its use as a robust tool for understanding this construct, allowing EEC-ALI to be used in large-scale measurements and differentiated assessments to better guide research and intervention in student populations.

The limitations of this study are that the nature of the sample prevents its extrapolation to the public at large, meaning that the results are only applicable to subjets with similar charateristics to the respondents, who were students of CRUCH universities. Further studies should test the use of this scale with other populations, and assess the external validity of the instrument by examining relations of the assessed domains with measures of variables that are expected to be related according to the literature. 


\section{Referencias}

Abad, F., Garrido, J., Olea, J., \& Ponsoda, V. (2006). Introducción a la Psicometría: teoría clásica de los test y teoría de la respuesta al ítem. Madrid: Universidad Autónoma de Madrid.

Abad, F., Olea, J., Ponsoda, V., \& García, C. (2011). Medición en ciencias sociales y de la salud. Madrid: Síntesis.

Barraza, C., \& Ortiz, L. (2012). Factores relacionados a la calidad de vida y satisfacción en estudiantes de enfermería. Ciencia y Enfermería, 18(3), 111119. http://dx.doi.org/10.4067/S0717-95532012000300011

Black, D. (2007). Compulsive buying disorder: a review of evidence. CNS Spectrums, 12(2), 124-132. http://dx.doi.org/10.1017/S1092852900020630

Browne, M., \& Cudeck, R. (1993). Alternative ways of assessing model fit. In: K. A. Bollen y J. S. Long (Eds.), Testing structural equation models (136-162). Beverly Hills, CA: Sage.

Brown, T. (2006). Confirmatory factor analysis for applied research. New York, NY: Guilford.

Campbell, C. (2004). I shop therefore I know that I am: the metaphysical basis of modern consumerism. En: K. M. Ekstrom y H. Brembeck (editores). Elusive Consumption. Berg. Nueva York.

Coward, K., \& Goldsmith, R. (2007). The Influence of consumer decisionmaking styles on online apparel consumption by college students. International Journal of Consumer Studies, 31, 639-647. http://dx.doi.org/10.1111/j.14706431.2007.00615.x

Denegri, M., Fernández, F., Iturra, R., Palavecinos, M., \& Ripoll, M. (1999). Consumir para vivir y no vivir para consumir. Temuco: Ediciones Universidad de La Frontera.

Denegri, M., \& Martínez, G. (2004). ¿Ciudadanos o consumidores? Aportes constructivistas a la educación para el consumo. Revista de Educación, 37 , 101-116.

Denegri, M. (2010). Introducción a la Psicología Económica. Bogotá: PSICOM Editores.

Denegri, M., González, Y., Cabalín, K., Ferrada, M., Godoy, M., \& Sepúlveda, J. (2010). Compra por impulso en profesores de educación básica de la ciudad de Temuco. Boletín de Investigación Educacional, 25(1), 183-198.

Denegri, M., Sepúlveda, J., \& Godoy, M. (2011). Actitudes hacia la compra de alimentos y el consumo de estudiantes de Pedagogía y profesores en ejercicio en Chile. Psicología del Caribe, 28(2), 1-23.

Denegri, M., Alí, Í., Novoa, M., Rodríguez, C., Del Valle, C., González, Y., Etchebarne, M. S, Miranda, H., \& Sepúlveda, J. (2012). Relaciones entre las escalas actitudes hacia el dinero en la compra: Un estudio en estudiantes de pedagogía de Chile. Revista Interamericana de Psicología, 46(2), 229-238.

Denegri, M., García, C., González, N., \& Sepúlveda, J. (2014). ¿Educadores o consumidores? Discrepancia del Yo, Consumo y Valores materiales en Estudiantes Chilenos de Pedagogía. Actualidades Investigativas en Educación, 14, 1-20.

Denegri, M., Elgueta, H., Peñaloza, V., \& Sepúlveda, J. (2015). Escala de Estilos hacia la compra, validación en estudiantes universitarios chilenos. Unpublished manuscript presented at 1st Latin American Conference of Psychology, Bogota, 2015. 
Díaz, R., Carús, M., Macossay, C., \& Barbosa, I. (2010). Efecto del estilo de vida en los hábitos y conductas alimentarias en universitarios. Revista Exploratoris, 1. 1 - 6

Dittmar, H. (2005). Compulsive buying--a growing concern? An examination of gender, age, and endorsement of materialistic values as predictors. British Journal of Psychology, 96(4), 467-491. http://dx.doi.org/10.1348/000712605X53533

Espinoza, L., Rodríguez, F., Gálvez, J., \& McMillan, N. (2011). Hábitos de alimentación y Actividad Física en Estudiantes Universitarios. Revista Chilena de Nutrición, 38(4), 458-465. http://dx.doi.org/10.4067/S0717$\underline{75182011000400009}$

Ferrari, M, Luna-Arocas, R., Cap. 3.11: Consumiendo belleza y emociones. El papel de la actitud hacia la ropa y la imagen corporal. En El Consumo y la Adicción a las Compras. Diferentes Perspectivas, Ed. de la Universidad del País Vasco, 2001. Gebaüer, M., Schäfer, L., \& Soto, E. (2003). Compra impulsiva en estudiantes universitarios con diferente nivel de formación en economía de la Universidad de La Frontera. Tesis para optar al grado de Licenciado en Psicología. Temuco: Departamento de Psicología, Universidad de La Frontera.Flight, R., Roundtree, M., \& Beatty, S. (2012). Feeling the urge: affect in impulsive and compulsive buying. Journal of Marketing Theory and Practice, 20(4), 453-465. http://dx.doi.org/10.2307/23461978

$\mathrm{Hu}, \mathrm{L} ., \quad \&$ Bentler, P. (1999). Cutoff Criteria for Fit Indexes in Covariance Structure Analysis: Conventional Criteria versus New Alternatives. Structural Equation Modeling, 6(1), 1-55. http://dx.doi.org/10.1080/10705519909540118

Kukar-Kinney, M., Ridway, N., \& Monroe, K. (2009). The relationship between consumers' tendencies to buy compulsively and their motivations to shop and buy on the internet. Journal of Retailing, 85(3), 298-307. http://dx.doi.org/10.1016/j.jretai.2009.05.002

Kline, R. (2011). Principles and Practice of Structural Equation Modeling (3rd ed.). New York: University Press.

Kongsompong, K. (2006). Cultural diversities between Singapore and Australia: an analysis of consumption behavior. Journal of American Academy of Business, 9(2), 87-92.

Kranjecec, R., \& Polic, M. (2003, September 1-4). "Some Factors influencing Material Consumption of Students." Paper Presented at the 28th Annual Colloquium of the International Association for Research in Economic Psychology, Christchurch, Australia Lance, C., Butts, M., \& Michels, L. (2006). The sources of four commonly reported cutoff criteria: What did they really say? Organizational Research Methods, 9, 202-220. http://dx.doi.org/10.1177/1094428105284919

León, O., \& Montero, I. (2002). Métodos de investigación en Psicología y Educación. Madrid: McGraw-Hill.

Luna-Arocas, R. (1995). Los estilos de compra y la satisfacción del consumidor en el contexto de la Psicología Económica. Doctoral dissertation. Valencia: Universidad de Valencia.

Luna-Arocas, R. (1998). Actitudes y creencias sobre el dinero. Revista Latinoamericana de Psicología, 94, 84-92.

Luna-Arocas, R., \& Fierres, R. (1998). Incidencia en la compra por impulso en la ciudad de Valencia. Revista Investigación y Marketing, 60, 36-43. 
Luna-Arocas, R. (1999). Segmentos de consumidores según la escala de compra patológica. Revista de Investigación y Marketing, 77, 16-25.

Luna- Arocas, R. (2001). El consumo y la identidad un proceso de autocreación. Investigación y Marketing, 70, 6-15.

Luna-Arocas, R., Galluccio, C., Costa, F., \& Miranda, S. (2001). Consumption in Southern Europe (Spain, Portugal and Italy). Paper presentes at the $28^{\text {th }}$ Anual Colloquium of the International Association for Research in Economic Psychology, Bath, UK.

Luna-Arocas, R., \& Bech-Larsen, T. (2004). La compra por impulso de productos de alimentación. Investigacion y Marketing, 82, 6-12. Luna-Arocas, R., Puello,S., \& Botero, M. (2004). La compra impulsiva y el valor material en los jóvenes (Colombia). Psicología desde El Caribe, 14, 1-26.

Lysonski, S., Durvasula, S., \& Zotos, Y. (1996). Consumer decision-making styles: a multi-country investigation. European Journal of Marketing, 30(12), 10-21. http://dx.doi.org/10.1108/03090569610153273

Macias, A., Gordillo, L., \& Camacho, E. (2012). Hábitos alimentarios de niños en edad escolar y el papel de la educación para la salud. Revista Chilena de Nutrición, 39(3), 40-43. http://dx.doi.org/10.4067/S071775182012000300006

Martínez-Arias, R. (1995). Psicometría: teoría de los tests psicológicos y educativos. Madrid: Síntesis.

Marsh, H., Wen, Z., \& Hau, K. (2004). Structural equation models of latent interactions: Evaluation of alternative estimation strategies and indicator construction. Psychological Methods, 9, 275-300. http://dx.doi.org/10.1037/1082-989X.9.3.275

Martínez, L. (2007). Mirando al futuro: Desafíos y oportunidades para el desarrollo de los adolescentes en Chile. Psykhe, 16, 3-14. http://dx.doi.org/10.4067/S0718-22282007000100001

McDonald, W. (1994). Psychological associations with shopping: a moderator variable perspective. Psychology \& Marketing, 11(6), 549-568. http://dx.doi.org/10.1002/mar.4220110604

Montero, I., \& León, O. (2002). Clasificación y descripción de las metodologías de investigación en Psicología. Revista Internacional de Psicología Clínica y de la Salud, 2, 503-508.

Montero, I., \& León, O. (2005). Sistema de clasificación del método en los informes de investigación en Psicología. Revista Internacional de Psicología Clínica y de la Salud, 5, 115-127.

Moulian, T. (1997). Chile: Anatomía de un mito. Santiago: LOM.

Muthén, L., \& Muthén, B. (2007). MPLUS statistical analysis with latent variables. User's Guide. Los Angeles, CA: Muthén and Muthén.

Muthén, L., \& Muthén, B. (2010). Mplus user's guide. Los Angeles: Muthén y Muthén.

Nunnally, Jum. 1967. Psychometric theory. Nueva York: McGraw.

Pereira, F., Antunes, A., \& Nobre, S. (2011). O papel da publicidade na compra de produtos cosméticos. Comunicação e Sociedade, 19, 161-178. http://dx.doi.org/10.17231/comsoc.19(2011).904

Rodríguez, R., Otero-López, J., \& Rodríguez, R. (2001). Adicción a la compra: análisis, evaluación y tratamiento. Madrid: Ediciones Pirámide. 
Rodríguez, B., \& Molerio, O. (2012). Validación de Instrumentos Psicológicos Criterios Básicos. Universidad Central "Marta Abreu" de Las Villas. Editorial FEIJÓO: Cuba.

Schiffman, L., \& Lazar, L. (2005). Comportamiento Del Consumidor.México D.F: Pearson Educación

Schnettler, B., Mora, M., Miranda, H., Sepúlveda, J., Denegri, M., \& Lobos, G. (2012). Satisfacción con la Alimentación en personas Mapuches de la Región de la Araucanía, Chile. Revista Chilena de Nutrición, 39, 18-29. http://dx.doi.org/10.4067/S0717-75182012000100002

Schnettler, B., Miranda, H., Sepúlveda, J., \& Denegri, M. (2011). Satisfacción con la alimentación y la vida, un estudio exploratorio en estudiantes de la Universidad de La Frontera, Temuco-Chile. Psicología y Sociedade, 23(2), 426-435. http://dx.doi.org/10.1590/S0102-71822011000200024

Schnettler, B., Obreque, B., Cid, E., Mora, M., Miranda, H., Sepúlveda, J., \& Denegri, M. (2010). Influencia del País de origen en la toma de decisión de compra de alimentos: un estudio en consumidores de distinta etnia en Chile. Revista Latinoamericana de Psicología, 42(1), 1196-130.

Sproles, G., \& Kendall, E. (1986). A Methodology for Profiling Consumers' Decision-Making Styles. Journal of Consumer Affairs, 20(2), 267-279. http://dx.doi.org/10.1111/j.1745-6606.1986.tb00382.x

Tang, T., Luna-Arocas, R., \& Quintanilla, I. (2001). The Development of the Possession Obsession Scale and Money Ethic in Spain. Paper presentes at the $28^{\text {th }}$ Anual Colloquium of the International Association for Research in Economic Psychology, Bath, UK.

Tanksale, D., Neelam, N., \& Venkatachalam, R. (2014). Consumer decision making styles of young adult consumers in India. Procedia - Social and Behavioral Sciences, 133, 211-218. http://dx.doi.org/10.1016/j.sbspro.2014.04.186

Tarnanidis, T., Owusu-Frimpong, N., Nwankwo, S., \& Omar, M. (2015). A confirmatory factor analysis of consumer styles inventory: Evidence from Greece. Journal of Retailing and Consumer Services, 22, 164-177. http://dx.doi.org/10.1016/j.jretconser.2014.07.001

Troncoso, C., \& Amaya, J. (2009). Factores sociales en las conductas alimentarias de estudiantes universitarios. Revista Chilena de Nutrición, 36(4), 1090-1097. http://dx.doi.org/10.4067/S0717-75182009000400005

Van Raaij, F. (1993). Postmodern Consumption. Journal of Economic Psychology, 14, 541-563. http://dx.doi.org/10.1016/0167-4870(93)90032-G

Walsh, G., Mitchell, V., \& Hennig-Thurau, T. (2001). German consumer decisionmaking styles. Journal of Consumer Behaviour, 35(1), 73-95. http://dx.doi.org/10.1002/cb.146

Zumbo, B., Gadermann, A., \& Zeisser, C. (2007). Ordinal Versions of Coefficients Alpha and Tetha for Likert Rating Scales. Journal of Modern Applied Statistical Methods, 6(1), 21-29. http://dx.doi.org/10.22237/jmasm/1177992180 